\title{
IN MEMORIUM
}

\section{JOAN FitZPATRICK}

The international law community suffered a tremendous loss this past year with the death of Joan Fitzpatrick. Joan was an outstanding scholar, a committed teacher, and a tireless advocate on behalf of human rights victims around the world. She authored or edited six booksincluding casebooks on international law and human rights law-as well as more than fifty articles. Her book on states of emergency remains the authoritative treatment and she made important contributions as well on refugee rights, the death penalty, women's rights, and the enforcement of international norms in domestic courts.

Joan was a beloved teacher. At the University of Washington, where she taught for many years, she was a role model and inspiration for a generation of students, who twice elected her professor of the year and affectionately referred to her as Saint Joan.

But, above all, Joan was a committed practitioner and advocate. For her, human rights were not only an academic interest. For many years, she held leadership positions with Amnesty International and helped found the Center for Justice and Accountability. As Harold Koh observed, she was not the kind of human rights activist who loves human rights but not human beings. It is fitting that we remember Joan this week, only days after the Supreme Court heard oral argument in the Alvarez-Machain case, involving the Alien Torts Claim Act. Joan first became involved in human rights law working at the Justice Department on its brief in the landmark Filartiga case, which launched the modern era of Alien Tort Claims Act litigation. And she continued to work on most of the important human rights litigation since then, including playing a central role in the Alvarez-Machain case itself.

Joan was for years an active member of the Society. She served on the Executive Council and the Board of Editors of the American Journal of International Law and chaired the Committee on Annual Awards. She was a fixture at the Annual Meetings, where she often organized or spoke on panels. Her absence from this meetings leaves a huge hole.

I first got to know Joan when I joined the University of Washington faculty as a junior academic. She was a wonderful mentor and colleague. She is missed not only by those of us who had the privilege of knowing her, but also by all those on whose behalf she worked so passionately. 